\title{
Epidemiological characterization of leptospirosis in horses in the state of Pernambuco, northeastern Brazil
}

\author{
Caracterização epidemiológica da leptospirose \\ em equinos do estado de Pernambuco, nordeste do Brasil \\ José Romero Alexandre Alves ${ }^{1}$, Kalyne Danielly Silva de Oliveira', Diego Figueiredo da Costa', \\ Leise Gomes Fernandes', Severino Silvano dos Santos Higino', Clebert José Alves ${ }^{1}$, \\ Carolina de Sousa Américo Batista Santos ${ }^{2}$, Sergio Santos de Azevedo ${ }^{1 *}$
}

\begin{abstract}
An epidemiological survey aiming to determine the occurrence of anti-Leptospira antibodies and to identify risk factors was carried out in horses of the Pajeú microregion, state of Pernambuco. Sera from 100 horses from 38 properties in four counties in the region were examined by the microscopic agglutination test (MAT), using 24 Leptospira spp. serovars as antigens. Of the 100 samples tested, 28 (28\%) were positive. Most prevalent serovars were Patoc (35.71\%), Butembo $(32.14 \%)$ and Sentot (14.30\%). Supply of pasture as forage (odds ratio $=7.80 ; 95 \%$ confidence interval - 95\%CI $1.71-$ $35.50 ; \mathrm{p}=0.008$ ) was identify as risk factor. It is suggested the need for studies on agent isolation and characterization of its pathogenicity, as well as it is recommended the rodent control in deposits of feed and environment.
\end{abstract}

KEYWORDS: epidemiology; horses; leptospirosis; risk factors.

\begin{abstract}
RESUMO: Foi realizado um inquérito epidemiológico objetivando determinar a ocorrência de anticorpos anti-Leptospira e elencar os fatores de risco em equinos da microrregiáo do Pajeú, estado de Pernambuco. Foram examinados 100 soros de equinos provenientes de 38 propriedades de 4 municípios da região, pela prova de soroaglutinação microscópica (SAM), utilizando 24 sorovares de Leptospira spp. como antígeno. Das 100 amostras testadas, 28 (28\%) foram reagentes. Os sorovares mais frequentes foram Patoc $(35,71 \%)$, Butembo $(32,14 \%)$ e Sentot $(14,30 \%)$. O uso de pasto como volumoso (odds ratio $=7,80$; intervalo de confiança de $95 \%$ - IC95\% 1,71-35,50; p=0,008) foi identificado como fator de risco. Sugere-se a necessidade de estudos acerca do isolamento do agente e da caracterizaçáo de sua patogenicidade, bem como se recomenda o controle de roedores em depósitos de ração e no ambiente.
\end{abstract}

PALAVRAS-ChAVE: epidemiologia; cavalos; leptospirose; fatores de risco.

\footnotetext{
'Laboratório de Doenças Transmissíveis (LDT); Universidade Federal de Campina Grande (UFCG), Campus de Patos - Patos (PB), Brazil. ${ }^{2}$ Centro de Ciências Agrárias (CCA); UFCG, Campus II - Areia (PB), Brazil.

*Corresponding author: sergio@vps.fmvz.usp.br

Received on: 12/08/2014. Accepted on: 09/28/2016
} 
Leptospirosis is a zoonotic disease caused by bacteria of the genus Leptospira that affects several species of wild and domestic animals. It is of economic importance in horses because it causes reproductive problems in mares and affects the performance of racehorses (HAMOND et al., 2012). In these animals, the disease most often progresses asymptomatically, and when clinical signs are present, they can be confused with those of other diseases (НаSнimoto et al., 2007; Braga et al., 2011). Abortion in mares, birth of weak or premature fetuses, as well as recurrent uveitis in young horses may be indicative of Leptospira infection. However, a definitive diagnosis is possible only using laboratory techniques, such as bacterial isolation and antibody detection in serum (BraGA et al., 2011).

In Brazil, recent serologic surveys conducted using the microscopic agglutination test (MAT) point to a seropositivity rate ranging from 5.9 to $100 \%$ (CHIARELI et al., 2008; Moraes et al., 2010). Risk factors, such as the presence of rodents in breeding facilities and food storage sites, contact with infected animals, high population density, and inadequate management practices, should be taken into account when there is suspicion of the disease in the herd (BARWICK et al., 1997). Knowledge of animal species that act as reservoirs of prevalent serotypes in the region, and of serovars adapted to hosts and persistent in the environment, is of great importance in establishing the epidemiology of animal leptospirosis in a given habitat (Назнімото et al., 2010).

Thus, the aim of this study was to carry out an epidemiological survey for the presence of anti-Leptospira antibodies in horses in the municipalities of Sertão de Pernambuco, to verify the predominant serotypes and to identify risk factors associated with seropositivity.

Blood sera from 100 horses that were not vaccinated for leptospirosis were used. The sampling was done from June to November 2011 from 38 properties in four municipalities (Brejinho, Itapetim, Santa Terezinha, and São José do Egito) of the microregion of Pajeú, mesoregion of Sertão. The study area is located in the north-central state of Pernambuco, near the border with the state of Paraíba, and has climatic characteristics of a semi-arid northeastern region, with vegetation that is typical of the caatinga biome. The rainy season occurs between the months of January and May, with average annual rainfall of $591.9 \mathrm{~mm}$. It has temporary watercourses like the river Pajeú and its tributaries that run through most of the municipalities. Most of the properties that bred the horses in the study were small (up to 10 hectares), with pickets, cultivated pasture, corrals and stalls for the confinement of animals, and waterholes and wells to meet the water requirement. The predominant farming was semi-intensive, where the animals were let loose in the pasture during the day and were usually confined in individual stalls at night. They were fed a forage and concentrate feed. Horse breeding usually occurred jointly with other farm animals such as cattle and small ruminants.
The sample was designed to determine seropositive animals with Leptospira infection by performing a random selection of a predetermined number of animals. Sample calculation was performed using the Epi Info software program, version 6.04 , and the following parameters were considered:

- expected prevalence of $50 \%$;

- absolute error of 5\%;

- a confidence level of 95\% (Thursfield, 1995).

According to the calculations, the minimum number of animals to be selected was 94 . The selection of properties was made after contacting the owners and obtaining their consent.

Serological diagnosis of leptospirosis was performed using the MAT, as described by Galton et al. (1965) and Cole et al. (1973), by using a collection of live antigens comprising 22 pathogenic serovars (Australis, Bratislava, Autumnalis, Butembo, Castellonis, Bataviae, Canicola, Whitcombi, Cynopteri, Grippotyphosa, Hebdomadis, Copenhageni, Icterohaemorrhagiae, Javanica, Panama, Pomona, Pyrogenes, Hardjo, Wolffii, Shermani, Tarassovi, and Andamana), and two saprophytic serovars (Patoc and Sentot). The antigens were examined under a dark-field microscope prior to the tests in order to verify the mobility and presence of selfagglutination or contaminants. The sera were screened at a dilution of 1:100, and those with $50 \%$ or more agglutination were titrated in a geometric dilution series with a ratio of two. The titer of the dilution was the reciprocal of the highest dilution that was positive. The reaction was read under a light microscope (Zeiss Jena) with a dark-field condenser, $20 \times / 0.2$ objective lens (EpiPlan), and a $10 \times$ eyepiece at $200 \times$ magnification.

To analyze the possible risk factors, data were collected from the properties by using an epidemiological questionnaire related to the characteristics of the animals, management, and clinical signs of leptospirosis (Table 1). The analysis of risk factors was conducted in two stages via univariate and multivariate analyses. In univariate analysis, each independent variable was crossed with the dependent variable (serological status of the animal), and variables that presented a $\mathrm{p} \leq 0.2$ on the chi-square test were selected for multivariate analysis by using multiple logistic regression (Hosmer; Lemeshow, 2000). The level of significance in the multivariate analysis was $5 \%$. All analyses were performed using Statistical Package for the Social Sciences (SPSS) for Windows, version 12.0.

Of the 100 animals tested, 28 reacted to at least one of the 24 serovars of Leptospira spp. antigens used in the battery of antigens, resulting in a $28 \%$ seropositivity rate. This frequency is within the range of seropositivity of 5.9 to $100 \%$ for horses in Brazil (Chiareli et al., 2008; Moraes et al., 2010) and reflects natural exposure to infection, since the owners in the region studied do not usually vaccinate animals against leptospirosis, which could interfere in the serological diagnosis at some point. 
Table 1. Univariate analysis of risk factors associated with seropositivity for Leptospira spp. in horses in the microregion of Pajeú of Pernambuco, from June to November 2011.

\begin{tabular}{|c|c|c|c|c|}
\hline Variable & $\begin{array}{l}\text { Total number } \\
\text { of animals }\end{array}$ & No. of positives & $\begin{array}{c}\text { Frequency (\%) } \\
\text { of positives }\end{array}$ & $\mathbf{p}$ \\
\hline \multicolumn{5}{|l|}{ Municipality of origin } \\
\hline Brejinho & 26 & 12 & 46.15 & \multirow{4}{*}{$0.003^{*}$} \\
\hline Itapetim & 30 & 12 & 40.00 & \\
\hline Santa Terezinha & 24 & 2 & 8.33 & \\
\hline São José do Egito & 20 & 2 & 10.00 & \\
\hline \multicolumn{5}{|l|}{ Sex } \\
\hline Male & 63 & 14 & 22.22 & \multirow{2}{*}{$0.147^{*}$} \\
\hline Female & 37 & 14 & 37.84 & \\
\hline \multicolumn{5}{|l|}{ Breed } \\
\hline Mixed race & 84 & 24 & 28.57 & \multirow{2}{*}{1.000} \\
\hline Quarter horse & 16 & 4 & 25.00 & \\
\hline \multicolumn{5}{|l|}{ Age (years) } \\
\hline Up to 6 & 30 & 5 & 16.67 & \multirow{3}{*}{0.247} \\
\hline $7-10$ & 53 & 17 & 32.08 & \\
\hline$>10$ & 17 & 6 & 35.29 & \\
\hline \multicolumn{5}{|l|}{ Aptitude } \\
\hline Sport & 69 & 16 & 23.19 & \multirow{4}{*}{$0.174^{*}$} \\
\hline Reproduction & 15 & 7 & 46.67 & \\
\hline Draft & 8 & 4 & 50.00 & \\
\hline Rearing & 24 & 7 & 29.17 & \\
\hline \multicolumn{5}{|c|}{ Participation in aggregations } \\
\hline Yes & 25 & 7 & 28.00 & \multirow{2}{*}{1.000} \\
\hline No & 75 & 21 & 28.00 & \\
\hline \multicolumn{5}{|l|}{ Farming system } \\
\hline Extensive & 6 & 1 & 16.67 & \multirow{3}{*}{$0.046^{*}$} \\
\hline Semi-intensive & 59 & 22 & 37.29 & \\
\hline Intensive & 35 & 5 & 14.29 & \\
\hline \multicolumn{5}{|c|}{ Contact with other animals } \\
\hline Yes & 89 & 25 & 28.09 & \multirow{2}{*}{1.000} \\
\hline No & 11 & 3 & 27.27 & \\
\hline \multicolumn{5}{|l|}{ Wetlands } \\
\hline Yes & 71 & 18 & 25.35 & \multirow{2}{*}{0.498} \\
\hline No & 29 & 10 & 34.48 & \\
\hline \multicolumn{5}{|l|}{ Forage: pasture } \\
\hline Yes & 71 & 26 & 36.62 & \multirow{2}{*}{$0.006^{*}$} \\
\hline No & 29 & 2 & 6.90 & \\
\hline \multicolumn{5}{|l|}{ Forage: grass } \\
\hline Yes & 88 & 25 & 28.41 & \multirow{2}{*}{1.000} \\
\hline No & 12 & 3 & 25.00 & \\
\hline \multicolumn{5}{|l|}{ Concentrate } \\
\hline Yes & 76 & 20 & 26.32 & \multirow{2}{*}{0.684} \\
\hline No & 24 & 8 & 33.33 & \\
\hline
\end{tabular}


Table 1. Continuation.

\begin{tabular}{|cccc} 
Variable & $\begin{array}{c}\text { Total number } \\
\text { of animals }\end{array}$ & No. of positives & $\begin{array}{c}\text { Frequency (\%) } \\
\text { of positives }\end{array}$ \\
\hline Presence of rodents & 57 & 13 & 22.81 \\
\hline Yes & 43 & 15 & 34.88 \\
\hline No & & & 28.00 \\
\hline Abortion occurrence & 25 & 7 & 28.00 \\
\hline Yes & 75 & 21 & 1.000 \\
\hline No & & & 50.00 \\
\hline Uveitis occurrence & 2 & 1 & 27.55 \\
\hline Yes & 98 & 27 & 0.484 \\
\hline No & & & \\
\hline
\end{tabular}

*Variables selected and used in multiple logistic regression $(p \leq 0.2)$.

The serovar that reacted most often was Patoc, representing $35.71 \%$ of the reactions, followed by Butembo (32.14\%), Sentot (14.30\%), Copenhageni (7.14\%), Australis (7.14\%), and Hardjo (3.57\%). Although it does not cause disease, the Patoc serovar can be found casually in cultures of human clinical material (OMS, 2008). Delgado (2010) highlights the epidemiological importance of this serovar, because although rare, it has been isolated from clinical cases in other animal species, and may cross-react with pathogenic serovars.

The Butembo serovar occurred with a frequency of $32.14 \%$. Lilenbaum (1996) considers this serovar an incidental finding in cattle, and because its transmission occurs through contact with environments contaminated by leptospires eliminated from wild animals, it is believed that the presence of this serovar may also be an incidental finding in the equine species. The Sentot serovar was the third most common serovar in this study, with frequency of $14.30 \%$, a result similar to that found by Higino et al. (2012) in goats, but also in a semiarid region. Previously conducted studies have reported two cases of leptospirosis by the Sentot serovar in humans, thus emphasizing its zoonotic character (CoRRÊA et al., 1964).

From the univariate analysis of risk factors (Table 1), the following variables were selected $(p \leq 0.2)$ for the multiple logistic regression analysis: the municipality of origin, sex, aptitude, farming system, and supply of pasture as forage. The final logistic regression model identified the supply of pasture as a risk factor (odds ratio $=7.80$; 95\% confidence interval $-95 \%$ CI 1.71-35.50; $\mathrm{p}=0.008$ ). This risk factor can be justified by the existence of natural reservoirs of Leptospira spp. in the region, which eliminates the agent in the pasture. Moreover, the humid microclimate increases the viability of the agent and creates favorable environmental conditions that are closely related to the occurrence of the foci of infection (Genovez et al., 2006). Usually the forage, which is the main food source for animals in this region, comes from marshy areas near water holes and, sometimes, peri-urban areas near canals and dumps, which favor the occurrence of reservoirs in this environment. Therefore, natural reservoirs of the disease may eliminate the agent in the environment, as well as in the storage sites for the food provided to the animals, thereby increasing the risk of contamination (SiqueIra, 2012).

Approximately $28 \%$ of the animals were seropositive, and, among them, several reacted to pathogenic serovars, suggesting the need for isolating leptospires and characterizing their pathogenicity. Moreover, based on the analysis of risk factors, the control of rodents near food deposits, as well as in the environment, is recommended.
BARWICK, R.S.; MOHAMMED, H.O.; MCDONOUGH, P.L.; WHITE, M.E. Risk factors associated with the likelihood of leptospiral seropositivity in horses in the state of New York. American Journal of Veterinary Research, v.58, n.10, p.1097-1 103, 1997.
BRAGA, J.; HAMOND, C.; MARTINS, G; ABREU, R.N.; LILENBAUM, W. Ophthalmic alterations in horses with leptospirosis by serovar Icterohaemorrhagiae in Rio de Janeiro, Brazil. Pesquisa Veterinária Brasileira, v.31, n.2, p.147-150, 2011. 
CHIARELI, D.; MOREIRA, E.C.; GUTIÉRREZ, H.O.D.; RODRIGUES, R.O.; MARCELINO, A.P.; MENESES, J.N.C.; ALMEIDA, V.M.A. Frequência de aglutininas anti-Leptospira interrogans em equídeos, em Minas Gerais, 2003 a 2004. Arquivo Brasileiro de Medicina Veterinária e Zootecnia, v.60, n.6, p.1576$1579,2008$.

COLE, J.R.; SULZER, C.R.; PULSSELY, P.R. Improved microtechnique for the leptospiral microscopic aglutination. Journal of Applied Microbiology, v.28, n.5, p.976-980, 1973.

CORRÊA, M.O.A.; HYAKUTAKE, S.; NATALE, V.; TIRIBA, A.C.; GALVÃO, P.A.A. Leptospiroses humanas ainda não assinaladas no Brasil. Revista Instituto de Medicina Tropical de São Paulo, v.6, n.2, p.71-74, 1964.

DELGADO, P.M. Detecção sorológica da infecção por Toxoplasma gondii e Leptospira spp. em peixes-bois (Trichechus inunguis) de dois centros de preservação da Amazônia brasileira. 67f. Dissertação (Mestrado em Ciências) Instituto de Ciências Biomédicas, Universidade de São Paulo, São Paulo, 2010.

GALTON, M.M.; SULZER, C.R.; SANTA ROSA, C.A.; FIELDS, M.J. Application of a microtechnique to the agglutination test for leptospiral antibodies. Journal of Applied Microbiology, v.13, n. 1, p.81-85, 1965.

GENOVEZ, M.E.; DEL FAVA, C.; CASTRO, V.; GREGORY, L.; FERRARI, C.I.L.; LANÇA NETO, P.; SOUZA, M.R.; GOTTI, T.B.; OLIVEIRA, J.C.F.; PITUCO, E.M. Effect of Leptospira spp. serovar hardjo infection on reproduction of two beef nelore herds with different serological status. In: WORLD BUIATRIC CONGRESS, 2006, Nice, France. Resumos. Nice: 2006. p.24.

HAMOND, C.; MARTINS, G.; LILENBAUM, W. Subclinical leptospirosis may impair athletic performance in racing horses. Tropical Animal Health and Production, Edinburgh, v.44, n.8, p.1927-1930, 2012.
HASHIMOTO, V.Y.; GONÇALVES, D.D.; SILVA, F.G.; OLIVEIRA, R.C.; ALVES, L.A; REICHMANN, P.; MULLER, E.E.; FREITAS, J.C. Occurrence of antibodies against Leptospira spp. in horses of the urban area of Londrina, Paraná, Brazil. Revista Instituto de Medicina Tropical de São Paulo, v.49, n.5, p.327-330, 2007.

HASHIMOTO, V.Y.; GARCIA, J.L.; SPOHR, K.A.H.; SILVA, F.G.; ALVES, L.A.; FREITAS, J.C. Prevalência de anticorpos contra Leptospira spp. em bovinos, caninos, equinos, ovinos e suínos do município de Jaguapitã, estado do Paraná, Brasil. Arquivos do Instituto Biológico, v.77, n.3, p.521-524, 2010.

HIGINO, S.S.S.; ALVES, C.J.; SANTOS, C.S.A.B.; VASCONCELLOS, S.A.; SILVA, M.L.C.R.; BRASIL, A.W.L.; PIMENTA, C.L.R.M.; AZEVEDO, S.S. Prevalência de leptospirose em caprinos leiteiros do semiárido paraibano. Pesquisa Veterinária Brasileira, v.32, n.3, p.199-203, 2012.

HOSMER, D.W.; LEMESHOW, S. Applied logistic regression. 3.ed. New York: John Wiley and Sons, 2000. 375p.

LILENBAUM, W. Atualização em leptospiroses bovinas. Revista Brasileira de Medicina Veterinária, v.18, n.1, p.9-13, 1996.

MORAES, C.C.G.; KURODA, R.B.S.; PINHO, A.P.V.B.; YWASAKI, F.; MENESES, A.M.C.; MARTINS, A.V.; AMARAL JÚNIOR, J.M.; DIAS, H.L.T.; VASCONCELLOS, S.A. Pesquisa de anticorpos para sorovares de Leptospira interrogans patogênicas em equídeos criados na ilha de Algodoal, estado do Pará. Revista de Ciências Agrárias, v.2, n.53, p.188-194, 2010.

ORGANIZAÇÃO MUNDIAL DA SAÚDE (OMS). Leptospirosis humana: guía para el diagnóstico, vigilancia y control. Rio de Janeiro: Organización Mundial de la Salud, 2008. 127p.

SIQUEIRA, C.C. Leptospirose equina: estudo soroepidemiológico nas regiões metropolitana de Salvador e Recôncavo Baiano. $76 \mathrm{f}$. Dissertação (Mestrado em Medicina Veterinária Tropical) - Escola de Medicina Veterinária e Zootecnia, Universidade Federal da Bahia, Salvador, 2012. 